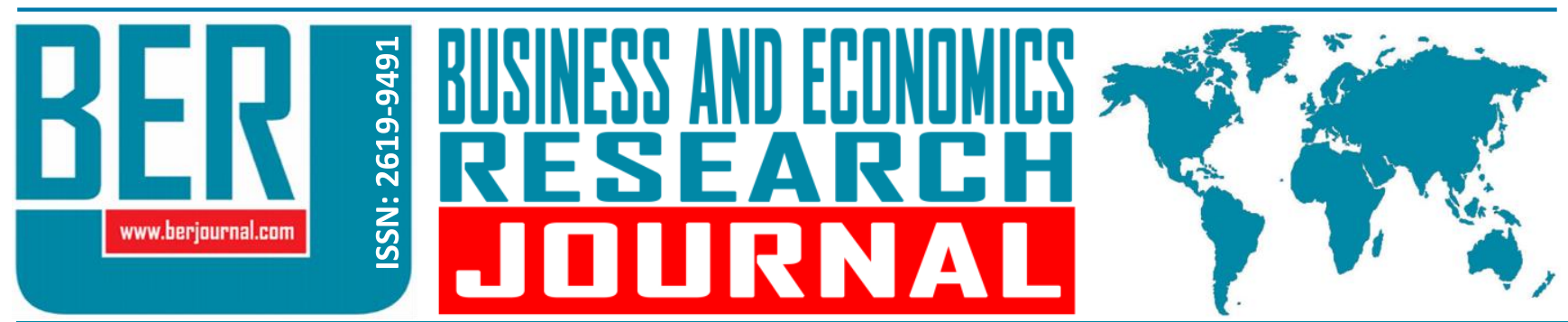

Business and Economics Research Journal Vol. 10, No. 2, 2019, pp. 557-574 doi: 10.20409/berj.2019.185

\section{Kent Markalaşması Faaliyetleri Üzerine Bir Araştırma: Karşıyaka/İzmir Örneği*}

\author{
${\text { Berkay Ozkaya }{ }^{a} \text {, Elif Deniz }}^{b}$
}

Öz: Bu çalışmanın amacı, İzmir'in Karşıyaka ilçesinin sosyal, kültürel ve ekonomik özellikler ışığında markalaşma faaliyetlerinin nasıl şekillendiğini incelemek, kent markalaşması çabaları kapsamında ilçe hakkında değerlendirmeler ve öneriler sunmaktır. Vaka analizinin uygulandığı çalışmada, yargısal örnekleme tekniği ile seçilen katılımcılarla yüz yüze görüşmeler yapılarak toplanan veriler ve elde edilen sonuçlar incelenmiş ve yorumlanmıştır. Markalaşma çabaları ve stratejileri doğrultusunda, Karşıyaka'nın marka ile ilgili kavramlar ve bileşenleri açısından durumu, mevcut markalaşma stratejileri ve marka kent yaratma süreci ele alınmış ve incelenmiştir. Elde edilen bulgulara göre, Karşıyaka marka kent olma yolunun neredeyse başındadır; ancak bir ana marka ile bağımlı marka mimarisi modeli kullanılarak ilçenin potansiyele sahip olduğu kültür, sanat ve spor alanlarında başarıyla markalaşabileceği görüşü hâkimdir. Sonuç olarak, markalaşma çalışmalarının, kendisini tamamen markalaşmaya adayacak, paydaşları bir araya getirecek, bütünsel ve kurumsal bir yapıda çalışacak ve Karşıyaka Belediyesi bünyesinde bir çatı girişim olarak kurulacak komisyonca yürütülmesinin en etkin ve verimli girişim olacağı ortaya çıkmaktadır.

\section{A Research on City Branding Activities: The Case of Karşıyaka/İzmir}

Abstract: The aim of this study is to investigate how branding activities of Karşlyaka County of izmir, Turkey are shaped in terms of social, cultural and economic characteristics; to make assessments about the county and to offer suggestions for urban branding efforts. In this study in which case study was implemented data was collected through face-to-face interviews conducted with participants selected by judgment sampling technique. The current status, structure in terms of brand components, current branding strategies and branding process of Karşlyaka County were analyzed in light of branding efforts and strategies. According to the results, Karşlyaka is in the process or being a branded city. However, the process needs to be integrated into the branded house model, to reveal Karşlyaka's potential success on the fields of cultre, art and sports. It is believed that branding activities should be carried out by a holistic and institutional committee established under the umbrella of Karşlyaka Municipality bringing all NGOs and the related economic, cultural and social actors together.
Anahtar Sözcükler: Marka, Markanın Bileşenleri, Kent Markalaşması, Markalaşma Stratejileri, Karşıyaka

JEL: M31, R11

\begin{tabular}{|c|c|}
\hline Geliş & : 28 Kasım 2018 \\
\hline Düzeltme & : 08 Ocak 2019 \\
\hline Kabul & : 18 Ocak 2019 \\
\hline Tür & :Araştırma \\
\hline
\end{tabular}

Keywords: Branding, Brand Components, City Branding, Branding Strategies, Karşıyaka

JEL: M31, R11

Received : 28 November 2018

Revised : 08 January 2019

Accepted : 18 January 2019

Type : Research

a Lecturer, University of Turkish Aeronautical Association, Izmir Vocational School of Aviation, Izmir, Turkiye, ozkayaberkay@gmail.com (ORCID ID: 0000-0001-6238-866X)

b Asst. Prof., PhD., Izmir Katip Celebi University, Faculty of Economics and Administrative Sciences, Izmir, Turkiye, elif.deniz@ikc.edu.tr (ORCID ID: 0000-0001-6873-5757) 


\section{Giriş}

Uzun dönemler boyunca ürün, eser ve hizmetlerden işlevsel fayda bekleyen insanlar, sosyal, kültürel ve ekonomik koşullardaki değişim ve gelişimle işlevsel faydanın ötesinde psikolojik faydalar da aramaya başlamıştır. Bu süreç özgün olmayı, farklılaşmayı ve markalaşabilmeyi her geçen gün daha önemli bir hale getirmiştir. Sağladığı çoklu faydalar itibarı ile zorlu süreçleri içerisinde barındıran markalaşma kavramı, uzun dönemli stratejik faaliyetlere intiyaç duymaktadır.

Marka olmanın sağladığı çoklu faydalar, günümüz rekabet ortamında kuvvetini artırma, etki alanını genişletme ve daha geniş alanlara yayılma arzusunda olan kentlere de etki etmiştir. Kentler, kenti oluşturan spor, sanat, kültür, turizm, ticaret, ulaşım, altyapı ve insan gibi birçok unsura temas etmek durumunda kalmıştır. Bu noktada daha bütünsel ve kurumsal bakış açısı ile planlı, uzun vadeli ve stratejik bir şekilde tanınır olmak, kalite algısı yaratmak, tüketilmeye değer olmak, başka bir deyişle cazibe merkezi haline gelmek kentler için temel amaç haline gelmiştir.

Karşıyaka ilçesinin kent markalaşması kapsamında literatürde incelenmemiş olması, çalışmanın özgün değeri olarak öne çıkmakta ve ilçenin markalaşmasına ilişkin gerçekleştirilen faaliyetler kent unsurlarını, marka temel kavram ve bileşenlerini ve kent markası yaratma sürecini kapsayıcı şekilde ele alınmaktadır. Kent markalaşmasının ele alındığı bu çalışmada, Karşıyaka'nın sosyal, kültürel ve ekonomik özellikleri ışı̆̆ında markalaşma faaliyetlerinin nasıl şekillendiğini incelemek, kent markalaşması çabaları kapsamında ilçe hakkında çeşitli değerlendirmeler ve öneriler sunmak amaçlanmaktadır.

\section{Literatür İncelemesi}

\subsection{Kent ve Kent Unsurları}

Kentler, günümüzde kapitalist sistemin sertleşmiş yapısı ile birlikte yalnızca topluluklar halinde yaşanan ve birçok iş kolunu içerisinde barındıran kalabalık nüfuslu alanlar olmanın ötesine geçerek, ürün gibi paketli, reklama konu, pazarlanır bir yapıya evrilmiştir. Bu durum, işletme terminolojisine de "kent markalaşması/kentsel markalaşma" kavramı olarak dâhil olmuştur (Hanna ve Rowley, 2008: 61; Akturan ve Oğuztimur, 2016: 117). Söz konusu kavram, temelde gelişmekte olan ülke kentleri için kalkınmayı ifade eden bir kavram olarak ortaya çıkmıştır. Kent markalaşması, kent yapısında özgün niteliklerin ortaya çıkarılması ile birlikte bir imaj yaratılmasını ve kentin tanıtılmasını sağlamaktadır. Bir sürecin ifadesi olan kent markalaşması, ürün ve hizmetlerin markalaşması için gerçekleştirilen stratejik çalışmaların bir kente uygulanması anlamına gelmektedir. Bu süreç, kente ait birçok bileşeni hatta kente ait duyguları dahi içeren inançlar kümesinden oluşmaktadır. Sürecin sonunda ise kenti bir cazibe merkezi haline getirerek dış yatırımcıların, turistlerin, gelişmiş nüfusun vb. kente çekilmesi amaçlanmaktadır (Peker, 2006: 21; Kaypak, 2010: 210).

Birçok otoriteye göre kentlerin markalaşma süreçleri kentin rekabet gücü, kalitesi, tarihi, yaşam biçimi, kültürü gibi unsurlara bağlı olarak şekillenmektedir. Anholt (2006) da kentlerin markalaşma potansiyellerini değerlendirdiği “Kent Markalaşma Altıgeni" nde kentin kültürüne, bilim, sanat ve spor ile olan bağına, eğitim, ticaret ve istihdam olanaklarına, park, bahçe ve yeşil alanlarına, ulaşım, sağıık ve konaklama olanaklarına ve kent insanına dikkat çekmektedir (Anholt, 2006: 18-31).

Yerel yönetimler, kent markalaşması sürecinde gerek çalışmaları ve düzenlemeleri ile gerekse yaratacağı stratejik plan ve alacağı kararlar ile kentlerin markalaşma çalışmalarında kilit rol oynamaktadır. Sürecin idaresinden ve paydaşların süreç ile bütünleşmesinden direkt sorumlu olan yerel yönetimler, kent markalaşmasında en önemli unsurlardan biri kabul edilmektedir (Parkerson ve Saunders, 2005: 259; Başçı, 2006: 58). Özel sektörün, markalaşma çabasında olan kentlerdeki varlığı ve kent ile bütünleşme seviyesi de sürece direkt etki eden unsurlardan biri olarak değerlendirilmektedir. L'Oreal ile Paris kentinin, Avrupa İnsan Hakları Mahkemesi ile Strasbourg kentinin uyumu söz konusu kentlerin markalaşmasında ve markalaşacakları alanlarda önem arz etmektedir (Kırgız, 2011: 27). Benzer şekilde turistik faaliyetler, kongreler ve aktiviteler de markalaşma için önemli unsurlar arasında kabul edilmektedir. OktoberFest ile Münih kenti, Burning Man 
etkinliği ile Nevada bölgesi, The International Motor Show (IAA) ile Frankfurt ve Hannover kentleri birlikte anılmakta ve bu etkinlikler söz konusu kentlerin markalaşmasında ve turistlerin kenti ziyaret etme isteği duymalarındaki önemli sebepler arasında sayılmaktadır (Başpınar, 2015: 34; www.burningman.org; www.genctur.com.tr; $\underline{w w w . i a a . d e)}$.

Spor, sanat ve eğitim de kentlerin markalaşmasında göz ardı edilemez unsurlar olarak kabul edilmektedir. Wimbledon Tenis Turnuvası ile birlikte Arsenal, Chelsea ve Tottenham gibi dünyaca ünlü futbol kulüplerine ev sahipliği yapan Londra kentinin ve Rönesans Dönemi sanatını günümüze taşıyan Floransa, Venedik ve Roma kentlerinin markalaşmasında sanatın ve sporun ne denli etkin rol oynadığı göz ardı edilemez olarak değerlendirilmektedir. Oxford, MIT ve Harvard gibi dünyaca ünlü üniversiteler, bulundukları kentlerin eğitim alanında da markalaşmalarına fırsat tanımaktadır. Marka değeri yüksek eğitim kurumları, entelektüel ve üst düzeyde eğitim talebi olan nüfusun, söz konusu kentleri cazibe merkezi olarak görmelerini sağlamakta ve eğitimin kent markalaşmasındaki önemini ortaya çıkarmaktadır (www.bleacherreport.com; www.wimbledon.com; www.nctraveler.com; www.topuniversities.com).

ìkamet ettiği kentlerde aradığını bulamayan kitlelerin ziyaret taleplerine yön veren diğer unsurlar ise kültür, tarihi miras, doğal güzellikler ve iklim olarak kabul edilmektedir. Söz konusu alanlar bulundukları bölgelerin ekonomik kazanımlar elde etmesini sağlarken, birer tanıtım ögesi olarak da kullanılabilmektedir. Kentlerin iklim ile bütünleşik hareket etme kabiliyeti, kentlerde gerçekleştirilecek etkinliklerin de cezbedici bir hal almasına olanak sağlamaktadır (Başpınar; 2015: 38-39). Altyapı, ulaşım, yatırım, yerleşim, sağlık, eğitim, konaklama, telekomünikasyon, turizm ve mimari gibi faktörler kentlerin markalaşmasında önem arz etmektedir. Bunlar, kentlerin tercih edilmesi noktasında tüketici kararlarını etkileyen faktörler olarak kabul edilmektedir (Kırgız, 2011: 30-31; Başpınar, 2015: 41-42). İnsan ise kentleri, kentlerin geçmişten günümüze uzanan ve bugünden yarına aktarılacak olan kültürünü oluşturan unsur olarak dikkat çekmektedir. Spor, kültür, sanat, altyapı, yatırım, ulaşım gibi unsurların ötesinde kabul edilen insan unsuru, temas ettiği diğer tüm unsurların da değişmesine olanak sağlamaktadır. Sürecin tamamına direkt ya da dolaylı olarak müdahale etme kabiliyeti dikkate alındığında insan, kent markalaşması hususunda üzerinde özellikle durulması gereken unsur olmaktadır (Açıkgöz, 2007: 35; Kırgız, 2011: 30).

\subsection{Kent Markası Oluşturma Süreci}

Kent markalaşması süreci, öncelikle kentlerin "Kentimiz, hedef kitle dikkate alındığında, hangi özelliği/özellikleri ile diğer kentlere göre farklıdır/farklılaşabilmektedir?" sorusunu verecekleri cevaba bağlıdır. Fakat markalaşma sürecinde karar verici ve uygulayıcıların olası karmaşıklıkları, hedef kitlede yer alan bireylerin talep ve beklentilerinin farklılıkları, kenti oluşturan unsurların çokluğu ve buna bağlı olarak konumlandırma çalışmalarında oluşabilecek dağınıklıklar/belirsizlikler kentlerin markalaşmasını, ürün ve hizmetlerin markalaşmasından daha zorlu bir hale getirmektedir. Bu noktada süreç, bir bütün olarak ele alınmalı ve kent paydaşlarının tamamı, mümkün olan en üst düzeydeki gönüllülükle sürece dâhil edilmelidir. Bu durum kentlerin sosyal ve kültürel yapıları, ilke ve değerleri ile bütünlük içerisinde ilerleyecek bir kent markalaşması sürecinin oluşmasına olanak sağlamaktadır (Arslan, 2015: 43; Coşkun vd., 2004: 67-68; Seisdedos ve Vaggione, 2005: 1-2).

Markalaşma süreci, kentlerin doğası gereği pek çok parametreye bağlı değerlendirilmekle birlikte, temel olarak benzersiz ve arzu edilen olurken, tutarlı ve ölçülü vaatler sunmayı ifade etmektedir. Bu noktada kentler; planlama, planı geliştirme, uygulama ve değerlendirme evreleri ile markalaşma sürecini yönetmektedir. Planlama süreci, kentlerin, özellikleri itibarıly uygun stratejiler yaratmasına, rakiplerinden farklılaşabileceği noktaları tespit ederek kimlik ve imaj çalışması yapmasına imkân vermektedir. Takip eden süreç, mevcut planlama çalışmalarının hedef kitle ile uyumu kontrol edilerek, profesyonel müdahaleler ile birlikte günün koşullarına uygun plan geliştirmelerinin yapıldığı evredir. Uygulama evresi, marka ögelerinin kullanım koşullarının belirlendiği ve halkla ilişkiler çalışmalarının devreye sokulduğu evre olarak kabul edilmektedir. Son evre ise ortaya çıkan tepkilerin, kimlik ve imajın, planlama öncesi ve sonrası dönemin değerlendirmesinin ve düzenlemelerin yapıldığı evre olarak kabul edilmektedir (Mariotti, 2000: 117-119). 
Kent markalaşmasında stratejik yönetim ve kent markası olma süreçlerinin, kentin ihtiyaçları, beklentileri, kent misyonu, vizyonu ve hedefleri ile bütünleşik ve istekli bir çalışma oluşturularak gerçekleştirilmesi gerekmektedir. Stratejik Yönetim Süreci dikkate alındığında kentler için "Neredeyiz?" sorusuna cevap olacak bir durum analizine intiyaç duyulmaktadır. "Nereye ulaşmak istiyoruz?" sorusu ile birlikte kent vizyonu için paydaşların da sürece dâhil olduğu bütünleşik bir sistem oluşturarak çalışmak uygun görülmektedir. "Gitmek istediğimiz yere nasıl ulaşabiliriz?" sorusuna cevap niteliğinde stratejik plan hazırlanmalı ve bu planlar, içerisinde amaçları ve hedefleri de barındıran, kentin gerçekleri ile örtüşen bir süreci ifade etmelidir. "Başarımızı nasıl takip eder ve değerlendiririz?" sorusuna cevap niteliğinde yerel yönetimlerce oluşturulan kent vizyonu ve stratejik plan gibi süreçleri değerlendiren performans programları hazırlanmalıdır (Gökerik, 2013: 14; www.sp.gov.tr).

Durum analizlerinde sıklıkla kullanılan yöntem olan GZFT (SWOT) analizi, kurum ve kuruluşlardan şahıslara kadar herkesin uygulayabildiği bir yöntemdir. GZFT analizi, içsel analizde güçlü ve zayıf yönlerin görülmesini sağlamakta, dışsal analizde ise karşılaşılabilecek fırsatları ve tehditleri değerlendirme fırsatı sunmaktadır. İçsel analizde kurum içi iletişim, karar alma süreçleri, amaçlar, personel sayısı ve yetkinlik düzeyleri, eldeki varlıklar, altyapı ve kullanım seviyeleri gibi başıklar değerlendirilirken; dışsal analizde ulusal ve küresel rekabet koşulları, sektör ve planları gibi kurum kontrolü dışında seyreden başlıklar değerlendirilmektedir (Özden, 2013: 87-89; Bakır vd., 2017: 156).

Stratejik yönetim ve marka kent olma sürecindeki bütünleşme dikkate alındığında, kentlerin markalaşmasında şehir vizyonu da önem arz etmektedir. Kentler, vizyon oluştururken paydaşlardan herhangi birinin süreç dışı kalmamasına, eşit, adil ve çok sesli bir yapıda çalışımasına özen göstermelidir. Bu sebeple kent vizyonu yaratma sürecinde kent konseyi üyeleri, yerel yönetimler, kamu kurum ve kuruluşları, STK'lar, üniversiteler, odalar, vakıflar, kentliler vb. muhakkak sürece dâhil edilmelidir. Kentin demografik yapısı ile uyumlu, basit, anlaşılır ve odak noktası belli, anlaşılması kolay ve çekici, amaç-eylem uyumunu sağlayıcı, heyecan uyandırıcı ve gerçeklerle örtüşür bir gelecek öngören kent vizyonları sürecin bütünleşik ilerlemesinde önem arz etmektedir (Zeren, 2011: 188; Hacıoğlu, 2013: 67-68; Gökerik, 2013: 19).

Markanın etki alanı yalnızca sunulan hizmetler ve/veya ürünlerle ölçülmemekte, yaratılan kimlik ve imaj gibi kıstaslarla da değerlendirilmektedir. Bu sebeple kentler, oluşturacakları doğru kimlik ve konumlandırma ile doğru bir imaj yaratmaktadırlar (Altunbaş, 2007: 160). "Marka nasıl algılanmak isteniyor?” sorusuna verilen yanıt olan marka kimliği; kentin fiziksel, ekonomik, sosyal, kültürel ve tarihi birçok ögesi ile ortaya çıkmaktadır. Kentlilerce benimsenmiş bir kent marka kimliği bütünlük sağlanmasına vesile olmakta, kentte oluşacak istenmeyen durumlara karşı bir duyarlıık oluşmasını ve farklılaşmayı sağlamaktadır (Kavaratzis ve Ashworth, 2005: 508; Kaypak, 2010: 374-375; Polat vd., 2013: 49-50). Bu durum "Hedef kitle ile iletişimde rekabet üstünlüğü sağlayacak değerler nelerdir?” sorusunun cevabı niteliğindeki marka konumlandırmasının daha tutarlı bir yapıda gerçekleşmesini sağlamaktadır. Konumlandırma çalışmalarında kentin güçlü yönleri ve muadillerine göre farklılıkları ifade edilmektedir. İnsanların söz konusu kenti seçme sebebi/sebepleri yalnızca metalarla değil, kent ve kentli davranışları ile bütünleşik olarak değerlendirilmektedir. Kimlik ve konumlandırma kavramlarındaki uyum, seçim noktasında iletilen mesajların karmaşıklığını ortadan kaldırmaktadır (Kavaratzis ve Ashworth, 2005: 508; Avcılar ve Kara, 2015: 84; Başer, 2015: 37-38). "Marka nasıl algılanıyor?" sorusunun cevabı, söz konusu kentin marka imajı hakkındaki durumunu gözler önüne sermektedir. Marka imajının oluşmasında ise kentin nüfusu ve istihdam olanakları, sosyo-kültürel yapısı, kentteki suç oranları, eğlence olanakları, tarihi ve fiziki yapısı gibi birçok faktör rol oynamaktadır. Kent, markalaşma çalışmalarında yaratılan logo, slogan ve diğer yaratıcı çalışmalardan daha fazlasını sunarak, kentlilerin yaşam kalitesini ve mutluluk düzeylerini artırmalıdır. Kentlilerin marka imajı ile uyumu, ziyaretçilerin memnuniyet düzeylerine de olumlu etki etmektedir (Avraham, 2004: 472; Kavaratzis ve Ashworth, 2005: 508; Varlı, 2011: 48).

Kent markalaşması faaliyetlerinde başarıya ulaşan kentler genellikle zaman kaybına ve oyalanmaya tahammülü olmayan, kentlilerin desteğini alan bir süreç yaratan, işgücüne dayalı işlerde katma değerli bir etki alanına sahip, dışsal değişimlere uyumu yüksek, farkı fikir ve görüşlere açık ve kent markası konusunda tutarlı özellikler göstermektedir (Görkemli, 2012: 148). Stratejik yönetim ve kent markası yaratma süreçlerinde başarılı olan ve markalaşan kentler, kente ve kentlilere; yatırımları ve yatırımcıları kente çekme, 
gelir seviyesini, istihdamı ve refah düzeyini artırma, entelektüel seviyeyi yükseltme, olası ekonomik krizlerden daha az hasarla çıkma gibi faydalar sağlamaktadır (Torlak, 2015: 59).

Kentlerin, ilgili kentin değerini artırmak için ürün ve hizmetler gibi markalaşabileceği belirtilmektedir. Markalaşma, tüm stratejik unsurları bütünleşik ele alması bakımından önem arz etmekte (Rainisto, 2003: 4345) olup çokça ve ilgi ile çalışılan bir alan olmuştur. Birçok bileşene, iyi analize ve uzun soluklu bakış açısına ihtiyaç duyan kent markalaşması, 21. yüzyıl itibarı ile yoğun olarak çalışımaya başlayan bir alana dönüşmüştür.

Aaker (1996), kent markalaşmasının uzun zaman gerektiren zorlu bir süreç olduğunu ve bu sürecin beş aşamadan oluştuğunu belirtmektedir. Bu aşamalar sırası ile markanın stratejik analizi, marka kimliği yaratma, marka değerini oluşturma, markayı konumlandırma ve uygulama olarak ifade edilmektedir (Aaaker, 1996: 11-12).

Literatürde kentlerin markalaşması ile ilgili yapılan çalışmalarda, Rainisto (2003: 64-68), yerlerin markalaşması için gerçekleştirilecek uygulamaların dokuz temel başarı faktöründen söz etmektedir. Bu başarı faktörlerinden beş tanesi çekirdeği oluşturmakta ve bunlar; planlama grubu, vizyon ve stratejik analiz, kimlik ve imaj, kamu-özel ortaklığı ve liderlik olarak ifade edilmektedir. Çekirdeği çevreleyen diğer dört başarı faktörü ise politik birlik, küresel pazar, yerel kalkınma ve süreç eş zamanlılığıdır.

Hankinson (2004)'ın çalışmasında, kent markalarının kişilik sahibi olarak yorumlandığı ve tüketicileri ile iletişime dayalı ilişkiler kurulmasını sağlayan kavramsal bir model önerilmektedir. Bu modelin çıkış noktası ise marka kimliği, marka konumlandırması ve marka gerçekliğine dayanan temel marka olgusudur. Söz konusu çerçeve dört farklı marka bakış açısından oluşmaktadır. Algısal varlıklar olarak adlandııılan kategori birincil hizmet ilişkileridir ve marka deneyiminin temelini oluşturan eğlence alanlarını ve otelleri ifade etmektedir. iletişimciler olarak adlandıılan kategori, markanın altyapı ilişkilerini oluşturan marka uzantıları şeklinde tanımlanmaktadır. Iliş̧i olarak adlandırılan kategori medya ilişkilerini ifade ederken, değer artırıcı olarak adlandırılan kategori ise çalışanlar ve iç müşterileri de kapsayıcı şekilde tüketici ilişkilerini ifade etmektedir (Hankinson'dan aktaran Kavaratzis, 2009: 31-32).

Kavaratzis (2004: 66-69)'in çalışmasında marka kent iletişimi üzerinde durulmuş ve marka kentlerin iletişim çerçeveleri hakkında önerilerde bulunulmuştur. Üç kanal üzerinden mesaj veren kentlerin marka olarak değerlendirilmesinde birincil iletişim kanalı; mimari, peyzaj, tasarım, ulaşım, kültür, turizm altyapıları, kentli davranışları ve kamusal kent alanları gibi esas kaygısı iletişim faaliyetleri olmayan ögeler olarak sınıflandırılmakta ve istemsiz iletişim olarak adlandırılmaktadır. İkincil iletişim kanalı; bilişsel iletişim olarak adlandırılan ve reklam, halkla ilişkiler, grafik tasarım, logolar vb. gibi bilinen pazarlama uygulamalarını ifade etmektedir. Üçüncül grup ise ağızdan ağıza pazarlama olarak nitelendirilmektedir (Kavaratzis, 2004: 66-69).

Avraham (2004: 474-478) ise çalışmasında kent markalaşması için olumlu bir imaj oluşturulmasının, kötü imajın ve hoş bulunmayan çağrışımların stratejik hamleler ile ortadan kaldırılabileceğini belirterek, aşağıdaki çıkarımları ortaya koymuştur:

- Stratejik süreç ile hedef kitleyle iletişime geçilmesi,

- İlgi çekici etkinliklere ev sahipliği yapılması,

- Olumsuzu olumluya çevirecek yaklaşımların yaratılması,

- Kent ismi ve logosunda değişime gidilmesi,

- Kentlilerin de sürece dâhil edilebileceği bir imaj yaratılması,

- Etkili iletişim kampanyası ile yeni yatırımcılar ve turistler gibi değer yaratanların kente çekilmesi.

Trueman ve Cornelius (2006)'un çalışmasında yer markalama aracı olarak adlandırılan 5P (Presence, Purpose, Pace, Personality, Power) önerilmekte ve araçlar aşağıdaki gibi açıklanmaktadır (Trueman ve Cornelius'tan aktaran Kavaratzis, 2009: 32): 
- Var Olma (Presence): Net, farklılaşmayı başarmış, görünürlük sağlayan ve paydaşların istek ve ihtiyaçlarını karşılayabilecek çok katmanlı ve düzenli bir kimlik oluşturmak,

- Amaç (Purpose): Sivil toplumun gururlanmasını sağlayacak marka, yenilenmeye ve yeni fikirlere açık çok kültürlü toplum, uyumlu mesajlardan oluşan iletişim kanalları yaratmak,

- Tutum (Pace): Perspektifi dengeleyen ve gerilimi azaltan kamu - özel ortaklıklarını temin etmek,

- Kişilik (Personality): Kentin bakış açılarına ve kent gerçeklerine hassas yaklaşarak kapsayııı bir yapı tahsis etmek,

- Güç (Power): Sosyal amaçları ve yetkilendirmeyi, marka varlığını ve güvenini artırıcı şekilde tasarlamak.

Parkenson ve Saunders (2004) Birmingham kentinin markalaşması çalışmasında örnek olay, yarıyapılandırılmış nitel görüşme ve nicel araştırma yöntemlerini kullanmıştır. Çalışmada kentin marka boyutları; kültür, tarih, gece hayatı, alışveriş, altyapı, konut ve iş gibi maddi unsurlar, kişilik ve duygusal yönler gibi manevi unsurlar olarak ortaya konmuştur (Parkenson ve Saunders'tan aktaran Toksarı vd., 2014: 330-331).

De Carlo vd. (2009) gerçekleştirdiği çalışmada kenti ziyaret eden turistlerle yüz yüze anket çalışması uygulamış ve turistlerin seyahat nedenlerini, Milano hakkında algılarını, kentin ilgi çekici alanlarını, seyahat şekillerini ve memnuniyet düzeylerini ölçümleyerek kentin markalaşma sürecini incelemiştir. Bu çalışmada Milano kentinin marka boyutları; marka kişiliği ve sembolleri, ekonomik ve kültürel imkanları olarak ifade edilmiştir (De Carlo vd., 2009: 10-20).

Prayag (2010) çalışmasında, uluslararası ziyaretçilere mülakat ve yarı-yapılandırılmış anket uygulayarak Cape Town kentinin markalaşmasını incelemiştir. Çalışmada Cape Town kentinin markalaşmasında çağrışımlara ilişkin boyutlar ortaya koymuştur (Prayag, 2010: 462-485).

Nitel araştırma yöntemlerinden yüz yüze derinlemesine mülakat yönteminin uygulandığı çalışmalar dikkate alındığında Büyüksoy (2008: 106-126)'un çalışmasında kent markalaşması sürecini etkileyen özelliklerin teşhisi ve İstanbul kentinin güçlü bir marka haline getirilmesinde rol oynayacak güçlü ve zayıf yönler incelenmiştir. Bu kapsamda markanın tanımı, özellikleri, kent markası ve markalaşma süreci, İstanbul markası ve markalaşma süreci hakkında bulgulara ulaşılmıştır. Aray (2009: 106-126) çalışmasında Burdur'un genel imajı, çağrışımları, tanıtımı, potansiyeli ve geleceği hususunda açık uçlu sorular sormuş ve kentin marka kimliğine, konumlandırmasına ve vizyon çalışmalarına yönelik bulgular sunmuştur. Varlı (2011: 68-121) ise çalışmasında, İstanbul'un Avrupa Kültür Başkenti olarak markalaşma sürecindeki iletişim temelli faaliyetlerini analiz etmiştir. Bu kapsamda, iletişim faaliyetlerinin seçimi, gerçekleşmesi, etkileri ve kente katkılarına yönelik sorular sorulmuş ve bu faaliyetlerinin kentin markalaşma sürecine etkileri tartışılmıştır.

Bir başka çalışmada Tarsus'un algısına, güçlü ve zayıf yönlerine, markalaşması için yapılması gerekenlere ve potansiyeline ilişkin incelemeler yapılmış ve kentin markalaşma süresinde ekonomik, sosyal ve kültürel gelişime ihtiyaç duyduğu ifade edilmiştir (Pala, 2013: 58-88).

Egeli (2017: 88-112) ise İzmir'in bir evrensel marka kent olma yolundaki eksikliklerini, atması gereken adımları ve ileriye dönük hedeflerini ortaya koymaya çalışmıştır. Bu kapsamda İmir'in marka faaliyetleri, yerel yönetimleri, GZFT analizi, turizm eğilimleri, sembol, marka şehir aşamaları, gelecek durumu, marka hikâyesi ve imajı, model ve rakip şehir unsurları incelenmiştir.

Kent markalaşması, kentlerin birçok unsura temas etmesinden ve kent markası oluşturma sürecinin karmaşık yapısından ötürü, işletme, halkla ilişkiler ve tanıtım, mimarlık, üretim yönetimi ve pazarlama, uluslararası ticaret, turizm, kamu yönetimi ve şehir bölge planlama gibi birçok alanda araştırmalara konu olmaktadır. Bu çalışmada kent markalaşması bağlamında, alan yazında ele alındığına rastlanılmayan Karşıyaka ilçesine yönelik kent markalaşma süreci geniş bir perspektifte incelenmiştir.

\section{Metodoloji}

\subsection{Araştırmanın Amacı ve Önemi}


Rekabet koşullarının günden güne sertleşmesi ve kapitalist sistemin dünya ekonomisindeki hâkim durumu dikkate alındığında, kentler de bulundukları pazarı oluşturan pastadan daha büyük pay alma arzusuyla hareket etmektedirler. Bu durum, kentleri de küresel işletmelere benzer bir yapıya dönüştürmüştür (Akturan ve Oğuztimur, 2016: 119). Kentler de potansiyelleri ve farklılaşabilecekleri alanlar doğrultusunda cazibe merkezi haline gelme gayreti göstermektedir.

Bu çalışmanın amacı İzmir'in Karşıyaka ilçesinin sosyal, kültürel ve ekonomik özellikleri ışığında markalaşma faaliyetlerinin nasıl şekillendiğini incelemek, kent markalaşması çabaları kapsamında ilçe hakkında çeşitli değerlendirmeler ve öneriler sunmaktır. Karşıyaka ilçesinin kent markalaşması kapsamında literatürde incelenmemiş olması çalışmanın özgün değeri olarak öne çıkmaktadır. Ayrıca takip eden süreçte gerçekleştirilecek akademik ve stratejik çalışmalara, kent markalaşması faaliyetleri özelinde önayak olacak olması ve kent markalaşması hususunda bir farkındalık yaratma potansiyeli bu çalışmanın önemi olarak ortaya çıkmaktadır. Çalışmada kent markalaşmasının sağladığı faydalar Karşıyaka ilçesinin potansiyelleri dikkate alınarak, ilçenin markalaşması için yapılanlar ve yapılacaklar hususunda Karşıyaka'nın tanınan ileri gelenlerinin bilgi ve düşüncelerine başvurulmuştur. Vaka analizi ve kalitatif araştırma yöntemi ile gerçekleştirilen çalışmada kent markalaşması kapsamında Karşıyaka'nın markalaşma faaliyetleri, mevcut durum ve potansiyeli ele alınmış, bu bağlamda katılımcılar ile yüz yüze yapılan görüşmelerden elde edilen cevaplar yorumlanmış ve irdelenmiştir. Araştırmanın amacı dâhilinde katılımcılara markanın temel kavramları, bileşenleri, markalaşma stratejileri ve kent markası yaratma süreci konularında kapsayıcı sorular sorulmuştur. Araştırma soruları 4 grup olarak aşağıda belirtildiği gibidir;

Soru Grubu 1: Karşıyaka'nın marka ile ilgili temel kavramlar açısından değerlendirilmesine yönelik aşağıda yer alan sorular sorulmuştur:

- Mevcut logo, slogan ve maskot Karşıyaka kimliğini yansıtmakta/karşılamakta mıdır? Karşılıyor ise hangi yönlerden karşılamaktadır? Karşılamıyor ise önerileriniz nelerdir?

- 35,5 nasıl ortaya çıkmıştır? Bir farklılaşma unsuru olarak neyi ifade etmektedir?

- Karşıyaka bir insan olsa, kişilik özellikleri bakımından nasıl bir insan olurdu?

- Karşıyaka'nın genel imajı Karşıyakalılar ve Karşıyaka'ya dışarıdan bakanların gözünden nasıl gözükmektedir?

Soru Grubu 2: Karşıyaka'nın marka bileşenleri açısından değerlendirilmesine yönelik aşağıda yer alan sorular sorulmuştur:

- Karşıyaka hangi yapılar, özellikleri, sektör ve bileşenleri ile bilinmektedir? Tanınırlığı yerel, ulusal ve uluslararası açıdan hangi seviyededir?

- Size neler Karşıyaka'yı çağrıştırmaktadır?

- Karşıyakalılar bir ilçe olarak Karşıyaka'ya ne kadar bağlıdır?

Soru Grubu 3: Karşıyaka'nın markalaşma stratejileri açısından değerlendirilmesine yönelik aşağıdaki soru sorulmuştur:

- Karşıyaka için bir markalaşma çalışması uygulanır ise, marka mimarisi modellerinden hangisinin uygulanması daha uygun olacaktır? Neden?

Soru Grubu 4: Karşıyaka'nın mevcut durum, misyon, vizyon ve stratejik hedefleri (kent markası yaratma süreci) açısından değerlendirilmesine yönelik aşağıdaki sorular sorulmuştur:

- Karşıyaka'nın güçlü yönleri nelerdir?

- Karşıyaka'nın zayıf yönleri nelerdir?

- Karşıyaka'nın karşılaşabileceği fırsatlar nelerdir?

- Karşıyaka'nın karşılaşabileceği tehditler nelerdir? 
- Mevcut vizyon ve misyon Karşıyaka ilçesi ve bileşenleri ile örtüşmekte midir? Alternatif önerileriniz var ise nelerdir?

- Yerel Yönetimler açısından stratejik amaçlar Karşıyaka için uygun ve yeterli midir? Karşıyaka'nın hedefleri ne olmalıdır? Ne şekilde markalaşmalıdır?

\subsection{Araştırmanın Yöntemi}

Nitel araştırmalar özellikleri itibarı ile kişilerin duygu, tecrübe, algı, anlayış ve fikirleri ile temellendirilen bir araştırma yöntemidir. Bütüncül bir yaklaşım ile birlikte gözlem, görüşme ve doküman analizlerinin yapıldığı, ele alınan konuyu keşif amacı güderek anlamlı bağlantılar ortaya çıkartmak maksadı ile metinlerin ve görüşlerin analiz edilip yorumlandığı yöntem olarak da ifade edilmektedir (Yıldırım, 1999: 9-10; Keegan, 2009: 11). Temel dayanak noktası olarak insan algı ve anlayışlarına odaklanan nitel araştırmalar, nicel araştırmalarda olduğu gibi ölçümlerle ilgilenmek yerine, anlamla ilgilenen "ne", "neden" ve "nası" sorularını sormaktadır. Sosyal olguların durağan olmamasından ötürü evrensellikten bahsetmek mümkün değildir ve bu sebeple nitel araştırmalar, sosyal bilimler için uygun kabul edilmektedir. Bu bağlamda nitel araştırmaların temel özellikleri şu şekilde ifade edilmektedir (Yıldııım, 1999: 10-11; Keegan, 2009: 90; Stake, 2010: 11-16):

- Akışa müdahaleden uzak, manüpilasyona müsaade etmeyen, doğal ortam odaklıve duyarlı araştırma,

- Müdahil olunan ve fikirleri bütünün parçası olarak değerlendiren araştırma anlayışı,

- Esnemeye müsaade eden, tecrübe ve algıları da ortaya koyan yorumlayıcı yaklaşım,

- Detaylı yaklaşım ile toplanan verilerden tümevarımcı bir anlayış ile anlamlı bir bütünlük ortaya koyma.

Bu çalışmada yukarıda belirtilen özellikler doğrultusunda nitel vaka analizi yöntemi uygulanmıştır. Vaka analizi; seçilen olayın, sürecin ya da olgunun bütünlüğü ve birliği dâhilinde, derinlemesine araştırmayı, seçilenin kendi doğal ortamında ve bağlamında incelenmesini, tüm karmaşık süreçleri de dikkate alarak mümkün kılmaktadır. Derinlemesine irdelemeler yapmak, katılımcılardan elde edilen görüş ve bakış açıları arasındaki benzerlik ve farklılıkları yakından anlamak ve aktarmak, bu hususta oldukça anlamlı ve fazla bilgi sunmak vaka analizi şeklinde ifade edilmektedir (Yin, 2002: 23; Punch, 2014: 144-147). Üç gruba ayrılan vaka analizleri; vakanın sahip olduğu kimi benzersiz özellikleri itibarıyla vakaya duyulan ilgi temeline dayanan içkin vaka analizi; olağan faaliyetlerin detaylı, titiz ve derinlemesine incelenmesi, geniş ve gelişmiş anlayış temeline dayanan enstrümental vaka analizi ve birden çok vakanın ele alınması temeline dayanan çoklu vaka analizi şeklinde ifade edilmektedir (Stake, 2005: 445-446). Bu çalışmada ağırlıklı olarak enstrümental vaka analizi çalışması uygulanmakta olup, içkin vaka analizine yönelik özellikler de bulunmaktadır. Söz konusu çalışmalarda 3 ya da 4 kadar az katılımcı ile çalışma yapılmakta, ilgili sorular konu hakkında ilgisi/bilgisi olan bu katılımcılara yönlendirilerek derinlemesine bilgi edinilmesi hedeflenmektedir (Ritchie ve Lewis, 2003: 484). Bu çalışma, bahsedilen tüm hususları destekleyecek şekilde ele alınmış, herhangi bir hipotez test etmemiş ve genelleme yapacak sonuçlar ileri sürmemiştir. Elde edilen bulgular, vakanın kendine özgü özellikleri kapsamında irdelenmiştir.

\section{3. Örneklem Seçimi ve Veri Toplama}

Nitel vaka analiz yöntemi kapsamında ele alınan çalışmada araştırmaya konu vaka Karşıyaka/izmir Örneği olarak seçilmiştir. Çalışmada arzu edilen niteliklere sahip, erişimi kolay olan kişileri belirlemeyi ve seçmeyi sağlayan yargısal örnekleme tekniği kullanılmıştır. Söz konusu yöntemde, görüşme yapılacak kişilerin vaka konusunda bilgi sahibi olan kimselerden seçimi ve araştırma konusuna uygun nitelikteki katılımcıların belirlenmesi araştırmacıya bırakılmaktadır (Nakip ve Yaraş, 2017: 260).

Nitel araştırmalarda güvenilirlik ve geçerlilik tahsis etmek önem arz etmektedir. Onaylı rıza ve gönüllü katııım vesilesi ile mülakatçıları araştırma hakkında bilgilendirme, rıza gösterdiklerinden emin olma, baskı altında kalmamalarını sağlama vb. konularında taahhüt gerekmektedir. Nitel araştırmalarda çoğunlukla tercih edilen yüzyüze, derinlemesine, yarı-yapılandırılmış görüşme yöntemi bu çalışmada da kullanılmıştır. 
Derinlemesine ve yüz yüze görüşmelerde araştırmacı mülakatçılara sorular sormakta, gündem belirlemekte, gözlem yapmakta, dinlemekte, yanıt vermekte ve detaylıca inceleme yapılmasını sağlamaktadır. Yüz yüze derinlemesine gerçekleştirilen görüşmeler mülakatçının belirlediği zaman ve mekânda, asgari 1 saat sürecek şekilde gerçekleştirilmektedir (Berg, 2001: 32-33; Keegan, 2009: 71-80; Mills vd., 2010: 339). Belirtilen hususların tamamı dikkate alınarak ve uygulanarak çalışılmış ve vaka hakkında detaylı bilgi edinilerek, bağlamın yakından anlaşılması sağlanmıştır.

\subsection{Vakanın Seçimi ve Vaka Hakkında Genel Bilgiler}

Her geçen gün artan rekabet koşulları ana kentlerin önde gelen ilçelerinin söz konusu rekabet koşullarında edindikleri yer ve gerçekleştirdikleri markalaşma çalışmaları araştırımakta olup, araştırmanın konusu ile uyumu, erişilebilirliği ve araştırmacının vakaya duyduğu ilgi dikkate alındığında İzmir'in önde gelen ilçelerinden Karşıyaka vaka olarak seçilmiş ve araştırmaya konu olmuştur.

Karşıyaka hakkında genel bilgiler aşağıdaki gibidir:

- Karşıyaka il merkezine uzaklığı 7 km, genişliği 63,45 km² olan ve çevresi Yamanlar Dağı, Çiğli, Bayraklı ve İzmir Körfezi ile çevrelenen bir ilçedir.

- 1874 yılında belediye teşkilatı kurulan Karşıyaka, 15.05.1919 - 09.09.1922 tarihleri arasında Yunan işgalinde kalmıştır. İzmir'in kurtuluşuna ve Cumhuriyetin ilanına müteakip 1930 yılında İzmir Belediye sınırları içerisine girmiş ve 1954 yılında ilçe konumuna getirilmiştir.

- Bilinen en eski ismi olan Cordelio ismini Avrupa coğrafyasının en şanlı kahramanı "Richard Coeur de Lion (Aslan Yürekli Rişar)" ve/veya bölgenin en eski hâkim kültürü olan Luwi medeniyetlerinin dilinde "bahçelik yer/bahçe yeri geçidi" anlamına gelen kelimelerden aldığı rivayet edilmektedir.

- 2017 yılı itibariyle 342.062 kişinin yaşadığı, çağdaş uygarlı̆ın temellerinin atıldığı, iliada ve Odeysseia gibi nice destanların yazıldığı bu coğrafyada okur-yazarlık oranı \%99,992 olarak hesaplanmaktadır.

- Milli Mücadele'nin simgesi ve vatanperverliğin ifadesi olarak 1912 yılında kurulan Karşıyaka Spor Kulübü, Ulu Önder Gazi Mustafa Kemal Atatürk'ün isteği ile Türk Bayrağı'nı armasında taşıma şerefine nail olan ilk ve tek kulüp olarak bilinmektedir. Kulüp, tarih boyunca 17 farklı branşta faaliyet göstermiş ve bu branşlarda hem ulusal hem de uluslararası ölçekte onlarca kupa ve madalya ile şereflendirilmiştir.

- Birçok sanat eserine konu olan Karşıyaka; Attila İlhan, Salah Birsel, Şükran Kurdakul ve Yaşar Aksoy gibi nice kıymetli sanatçıların yetişmesine de vesile olmuştur.

- Karşıyaka TAFISA tarafından "Aktif Şehir" unvanı ile ödüllendirilmiştir ve aralarında Buenos Aires, Lozan, Liverpool, Ljubljana gibi şehirlerin olduğu "Global Aktif Şehir" uygulamasına dâhil edilen 10 kent arasındaki tek ilçe konumundadır.

- Karşıyaka, Avrupa Konseyi Yerel ve Bölgesel Yönetimler Kongresi tarafından "12 Yıldız Şehir", Avrupa Konseyi Parlamenterler Meclisi tarafından "Avrupa Diploması" ve "Avrupa Şeref Bayrağı" unvanları ile ödüllendirilmiştir.

- Karşıyaka birçok farklı inanç merkezine, köşke, müzeye ve anıta ev sahipliği yapmasının yanı sıra Türkiye Cumhuriyeti'nin Kurucusu Ulu Önder Gazi Mustafa Kemal Atatürk'ün annesini Zübeyde Hanım'ın kabrine de ev sahipliği yapmaktadır.

\subsection{Yüz Yüze Derinlemesine Görüşmeler}

Bu çalışma kapsamında mülakatçılarla gerçekleştirilen derinlemesine yüz yüze görüşmeler hakkında bilgiler aşağıdaki gibidir;

- 17.05.2018 tarihinde Araştırmacı, Gazeteci, Akademisyen, Yüksek Mühendis, Yazar, Şair Sn. Yaşar Aksoy ile telefonda görüşülmüştür. Araştırma hakkında ön bilgilendirme yapılmış, mülakat için 
randevu talep edilmiştir ve aynı gün çalışma hakkında detaylı bilgi ve kabul mektubu e-posta aracılığıyla kendisine iletilmiş, kendisi ile 21.05.2018 tarihinde saat 13.30'da Çeşme'de görüşülmüştür. Görüşme 58 dakika sürmüştür. Kabul mektubu mülakat arifesinde imzalanmıştır. Onay mektubu 20.08.2018 tarihinde ıslak imzalı olarak elden teslim alınmıştır.

- 18.05.2018 tarihinde Karşıyaka Belediyesi Eski Başkanı, KSK Eski Başkanı, KSK Divan Kurulu Eski Başkanı, Karşıyaka Kültür, Sanat ve Eğitim Vakfı Yönetim Kurulu Başkanı, Avukat Sn. Cihan Türsen ile telefonda görüşülmüştür. Araştırma hakkında ön bilgilendirme yapılmış, mülakat için randevu talep edilmiştir ve aynı gün çalışma hakkında detaylı bilgi ve kabul mektubu e-posta aracılığıyla kendisine iletilmiş, kendisi ile 22.05.2018 tarihinde saat 16.30'da İzmir Çankaya, Türsen Hukuk Bürosu'nda görüşülmüştür. Görüşme 100 dakika sürmüştür. Kabul mektubu mülakat arifesinde imzalanmıştır. Onay mektubu 17.08.2018 tarihinde ıslak imzalı olarak elden teslim alınmıştır.

- 23.05.2018 tarihinde Karşıyaka Belediyesi Str. Gel. Md. Müdürü Sn. Turan Ateş ile telefonda görüşülmüştür. Araştırma hakkında ön bilgilendirme yapılmış, mülakat için randevu talep edilmiştir ve aynı gün çalışma hakkında detaylı bilgi ve kabul mektubu e-posta aracılığıyla kendisine iletilmiş, 28.05.2018 tarihinde kendisi ile saat 09.30' da Karşıyaka Belediye Binası'nda görüşülmüştür. Görüşme 63 dakika sürmüştür. Kabul mektubu mülakat arifesinde imzalanmıştır. Onay mektubu 25.07.2018 tarihinde ıslak imzalı olarak elden teslim alınmıştır.

- 24.05.2018 tarihinde KSK Başkanı ve Büyükkarcı Grup Yönetim Kurulu Başkanı Sn. Turgay Büyükkarcı ile telefonda görüşülmüştür. Araştırma hakkında ön bilgilendirme yapılmış, mülakat için randevu talep edilmiştir ve aynı gün çalışma hakkında detaylı bilgi ve kabul mektubu e-posta aracılığıyla kendisine iletilmiş, kendisi ile 04.06.2018 tarihinde saat 13.30'da Büyükkarcı Grup Kemalpaşa Şubesi'nde kendilerinin şahsi ofisinde görüşülmüştür. Görüşme 45 dakika sürmüştür. Kabul mektubu mülakat arifesinde imzalanmıştır. Onay mektubu 18.08.2018 tarihinde ıslak imzalı olarak kargo yolu ile teslim alınmıştır.

- 23.06.2018 tarihinde Yaşar Holding Gıda Grubu Gıda İcra Başkan Yardımcısı ve KSK Yönetim Kurulu Üyesi Sn. Levent Dağhan ile telefonda görüşülmüştür. Araştırma hakkında ön bilgilendirme yapılmış, mülakat için randevu talep edilmiş ve aynı gün çalışma hakkında detaylı bilgi ve kabul mektubu eposta aracılığılla kendisine iletilmiş, kendisi ile 09.07.2018 tarihinde saat 10.00 'da Pınar Süt Mamulleri San. A.Ş. Yönetim Binası'nda görüşülmüştür. Görüşme 81 dakika sürmüştür. Kabul mektubu mülakat arifesinde imzalanmıştır. Onay mektubu 27.07.2018 tarihinde ıslak imzalı olarak kargo yolu ile teslim alınmıştır.

- 03.07.2018 tarihinde Temizocak Kuyumculuk ve Hassas Döküm San. ve Tic. A.Ş. Yönetim Kurulu Başkanı, Karşıyaka Sanayici ve İ̧ Adamları Derneği Kurucu Başkanı, KSK Eski Başkanı, Ege Ekonomiyi Geliştirme Vakfı Yönetim Kurulu Eski Başkanı ve Danışma Kurulu Üyesi Sn. Yılmaz Temizocak ile telefonda görüşülmüştür. Araştırma hakkında ön bilgilendirme yapılmış, mülakat için randevu talep edilmiştir ve aynı gün çalışma hakkında detaylı bilgi ve kabul mektubu e-posta aracılığıyla kendisine iletilmiş, kendisi ile 09.07.2018 tarihinde saat 14.00'da IAOSB Temizocak Kuyumculuk Yönetim Ofisi'nde gerçekleştirilmiştir. Görüşme 101 dakika sürmüştür. Kabul mektubu mülakat arifesinde imzalanmıştır. Onay mektubu 31.07.2018 tarihinde ıslak imzalı olarak elden teslim alınmıştır.

\subsection{Araştırmanın Güvenilirliği ve Geçerliliği}

Nitel araştırma yöntemi uygulanarak gerçekleştirilen bu çalışmada güvenilirlik ve geçerlilik aşă̆ıda belirtilen kıstaslarla sağlanmıştır (Lincoln ve Guba, 1985: 328; Berg, 2001: 57).

- Denetlenebilirlik: Çalışmanın denetlenebilirliği araştırmanın yöntemi başlığında adım adım açıklanmış ve detaylı bilgiler ile belirtilmiştir.

- Güvenilirlik: Araştırma kapsamında katılımcıların gönüllülük esası ile katıımları, arzu ettikleri zaman ve mekânda süre sınırı olmaksızın görüşülmesi, ses kayıtların çözümlemelerinin kendilerine ulaştırılması gibi güvenilirlik kıstasları ıslak imzalı kabul ve onay belgeleri ile sağlanmıştır. Ayrıca 
çalışmada yer alan bulgu ve yorumlar gerçekleştirilen mülakatların çözümlemelerine dayandırılmaktadır.

- Gizlilik: Katılımcıların şahsi bilgileri kendilerinin müsaade ve onayları dâhilinde görünür kııınmıs, detaylı şahsi bilgileri talep edilmemiştir. Mülakatlar esnasında elde edilen şahsi bilgiler ve ses kayıtları araştırma kapsamı dışında kalan üçüncü şahısların ulaşamayacağı şekilde muhafaza edilmiş ve kullanılan verilen onaylarına müteakip araştırmaya konu olmuştur. Çalışmanın tüm süreçleri gizlilik esaslarına uygun, danışman bilgisi ve onayı dâhilinde gerçekleştirilmiştir.

- Transfer Edilebilirlik: Çalışmanın aktarımlara konu olması ve gelecek çalışmalara katkı sağlaması maksadı ile literatür taraması, örneklem seçimi, araştırma yöntemi, veri ve yorumlar, onaylar ve izinler, sonuç, kaynakça bölümleri detaylı bir şekilde ele alınmış ve açıkça aktarılmıştır.

\subsection{Veri Analizi ve Araştırma Kısıtları}

Nitel araştırmalar entelektüel ve yorumsamacı bir analiz anlayışı ile tecrübe, sezgi, duygulardan faydalanan, yaratıcı, bütüncül bakış açısı gerektiren ve doğal ortamda çalışılan bir aktivite olarak ortaya çıkmaktadır. Notlara, görüşmelere, mülakatlara, fotoğraflara ve kayıtlara dayandırılan bir belgeye dönüştürülmektedir. Bu bağlamda zorlu ve saatler süren ses kayıtları, sabırla saflaştırılarak sağlıklı bir veri analizine intiyaç duymaktadır. Bu çalışmada söz konusu bilgiler ışığında "klasik araştırma modeli", enstrümental ve içkin vaka analizi bağlamında ele alınmıştır. Araştırmada verilerin toplanması, adım adım ilerlemeler ile gerçekleştirilmiş, mantıksal bir düzen, ahenk ve kategorizasyon ile açık ve anlaşılır öneriler ve sonuçlar elde edilmektedir (Stake, 2005: 445-446; Keegan, 2009: 205-206).

Araştırma, çalışma süresince artarak devam eden analizleri, katılımcıların söylemleri ve araştırmacının gözlemleri ile birleştirerek ve sentez ederek anlamlı bir bütün halinde aktarmayı amaçlamaktadır (Merriam, 2013: 161-168). Değerlendirmeler analiz edilip yorumlanırken doğası gereği yorumlama etkinliğinin araştırmacıya bağlı olduğu, genelleme kaygısından uzak, araştırma zamanı ve bağlamı ile sınırlı olarak farklı ve/veya benzer bakış açılarının anlamlandıııması ile ortaya çıkmaktadır. Bu yüzden kişi görüş ve davranışlarının farklılı̆ı dikkate alınarak ortaya koyulan bilgilerin göreceli ve/veya koşullu olduğu varsayılmakta, mümkün olduğu ölçüde görüşlerin açıkça ifade edilmesine teşvik edilmektedir. Sonuç olarak kişisel doğruların kesinlik taşınmamasından ötürü nesnel bir doğru ortaya çıkmamakta ve kişilerin bakış açıları doğrultusunda gerçekliğin anlaşılması amaçlanmaktadır (Keegan, 2009: 25).

Ayrıca nitel araştırmalarda sınırııık, kısıtııık ve varsayımlar araştırmanın çerçevesini belirlemektedir. Bunlar sırası ile vaka hakkında tanımlayıcı ve sınırlayıcı bir çerçeve sunulmasını, araştırmacının denetimi dışında gerçekleşebilecek ve sonucu etkileyebilecek etmenleri, araştırma hakkında genel fikir, görüş ve ön inançları ifade etmektedir (Hancock ve Algozzine, 2006: 71). Bu doğrultuda araştırmanın kısıtları aşağıdaki gibi açıklanmaktadır:

- Çalışma konusu kapsamında kent markalaşması faaliyetlerini gösteren tek bir vaka (Karşıyaka/izmir) ele alınmış ve çoklu vaka analizi yöntemine gidilmemiştir.

- Çalışma kapsamında mülakat yapılacak katılımcıların sınırlaması araştırmacının ulaşılabilirliği dâhilinde Karşıyaka'da uzun süredir bulunan veya doğma büyüme Karşıyakalı olan, Karşıyaka'ya ciddi ölçüde hâkim veya Karşıyaka'da önemli görevlerde bulunmuş bireylerden oluşmaktadır.

- Katılımcıların araştırmacı ile birlikte çalışmayı iş birliği ve gönüllülük esası ile kabul edecekleri, ilgili veri ya da bilgileri samimi ve açık bir biçimde paylaşacakları, çalışma başarı ile sonuçlanana kadar desteklerine devam edecekleri varsayılmaktadır. Mülakatçılardan, ses kayıtları yazılı hale getirildikten sonra değişiklik ve düzeltme yapıp yapmamaları hususunda bir okuma yapmaları istenmiş ve son görüşlerini onay mektubunu/formunu imzalayarak iletmeleri rica edilmiştir.

- Nitel araştırmaların doğası gereği verilerin toplanması, ses kayıtlarının çözümlenerek metin haline getirilmesi, okunup yorumlanması, katılımcı görüşlerini ve onaylarını almak üzere tekrar kendilerine iletilmesi, geri alınması, bulguların ve yorumların hassasiyetle, titiz ve tekrarlı şekilde 
değerlendirilmesi zaman alııı ve oldukça yorucudur. Bu sebeple söz konusu özellikler de araştırmanın kısıtları içerisinde değerlendirilmektedir.

- Nicel araştırmaların sosyal bilimler üzerinde yaratmış olduğu baskıdan ötürü, nitel araştırmalara yeteri kadar vakıf olmayan araştırmacılar ve ilgililer tarafından, geçerlilik ya da güvenilirlik açısından sorgulanması ya da araştırma yöntemi ve sunulan yorumların açıkça anlaşılamaması olasılığı varsayılmaktadır.

- Nitel bir çalışma olan bu araştırma, özellikleri itibariyle araştırma öncesi ve süresince bir hipotez geliştirilmesine ve test edilmesine konu olmamış, vakanın sınırları dışarısına çıkmak ve/veya kesin savlar sunmak söz konusu çalışmanın amaçları içerisinde yer almamaktadır.

\section{Bulgular ve Yorumlar}

Karşıyaka'nın, markanın temel kavramları açısından değerlendirilmesine yönelik sorulan soruların yanıtları dikkate alındığında katılımcılara göre Karşıyaka ilçesinin marka kimliği Atatürk, vatan sevgisi, Zübeyde Hanım ve kadın hakları, çağdaş, medeni, saygı ve hoşgörü temelli yaşam olarak ifade edilmektedir. Araştırmacı, Gazeteci, Yazar Sn. Yaşar Aksoy Karşıyaka'nın marka kimliğini "Nasıl ki İstanbul'un bir marka değeri varsa, tarihten ögeleri de taşıyorsa, Istanbul Ayasofya olmadan düşünülemiyorsa, Karşıyaka'nın da tarihini, kültürünü yansıtan bir yapı olması uygun olacaktır. "Cordelio" gibi "Kaf Sin Kaf" gibi ögeler Karşıyaka'yı yansıtmaktadır." şeklinde ifade etmektedir. Bu noktada Karşıyaka'nın kimliğine temas eden diğer ögelerin Karşıyaka Spor Kulübü, Eski Karşıyaka ve Kordelya olduğu belirtilmektedir. Yine Karşıyaka'nın kimliğini yansıtmak, farklılığı ve Karşıyakalılığı ifade etmek için kullanılan 35,5 kavramı da ilçe için önemli kimlik ögelerinden biri konumundadır. Karşıyaka Spor Kulübü ve Büyükkarcı Grup Yönetim Kurulu Başkanı Sn. Turgay Büyükkarcı Karşıyaka'nın marka kimliğini "Karşıyaka'nın, 35,5 ile diğer yerlerden kendini çok keskin çizgilerle ayıran bir yapısı vardır. 35,5 sadece spor kulübünün değil tüm Karşıyaka'nın simgesidir." şeklinde tanımlamaktadır. 35,5 kavramı yalnızca spor kulübünü ifade etmemekte, ilçenin kimlik ve kültür aynası olarak kullanılmaktadır. Kavram tanımlanırken Karşıyaka'nın kimlik ögeleri ile benzer şekilde ifade edilmekte ve ilçenin asli kimlik unsuru olarak tanımlanmaktadır.

Karşıyaka'nın kişilik özellikleri için kullanılan ifadeler ise kimlik ögelerinde kullanılan kimi ifadelerle benzerlik göstermektedir. Entelektüel, kültürlü, hür fikirli, yaratıcı, çeşitliliğe açık, otoriter, totaliter ve statükocu yaklaşımlara karşı dirençli olarak tanımlanmakta ve bu ifadeler belirgin bir şekilde açıklık kişilik özelliğini ortaya çıkartmaktadır. Ayrıca konuşkan, iddialı, sıcakkanlı, enerjik ve sempatik kişilik özellikleri de Karşıyaka için kullanılmakta ve bu özellikler itibarıyla ilçe dışadönüklük kişilik özellikleri taşımaktadır.

İlçenin imajı katılımcıların ifadelerine göre hem Karşıyakalıların hem de Karşıyaka'ya dışarıdan bakanların gözünden benzer şekilde tanımlanmaktadır. Karşıyaka Belediyesi ve Karşıyaka Spor Kulübü Eski Başkanı, Avukat Sn. Cihan Türsen Karşıyaka'nın imajı ile ilgili “Karşıyaka farklıdır. Karşıyaka hayranlık duyulan ve zaman zaman kıskanılarak izlenen bir kenttir. Bunu yaratmak oldukça zordur. Mesela Karşıyakalı şarkısı vardır; ipek siyah mantolu... Bu çok önemlidir çünkü siparişle yaratılamaz, olmaz." ifadelerini kullanmaktadır. ìlçenin, insanların sıklıkla yaşam alanı olarak tercih ettikleri ya da tercih etme arzusunda oldukları, sosyal yapısı kuvvetli, eğitim seviyesi ve entelektüelitesi yüksek bir ilçe olduğu söylenmektedir. Ayrıca çok kültürlü insan yapısına sahip fakat kozmopolit şehir yapısından nispeten sıyrılmış, özgün ve farklılaşmayı başarmış bir ilçe olarak ifade edilmektedir. Bununla birlikte Karşıyaka Spor Kulübü’nün ilçenin imaj algısına etkisinin oldukça yüksek olduğu da belirtilmektedir.

Karşıyaka'nın marka bileşenleri açısından değerlendirilmesine yönelik sorulan soruların yanıtları dikkate alındığında katılımcılara göre Karşıyaka ilçesinin yerel ve ulusal ölçekte oldukça yüksek düzeyde tanınırlığa sahip olduğu fakat bu tanınırığın planlı ve stratejik olmaması açısından eleştirilere konu olduğu ifade edilmektedir. Tanınırlığı yaratan temel unsurların ise Karşıyaka'nın kültürel birikimi, yaşam standartları, özgürlükçü ve demokrat insan yapısı, spor ve kültür-sanat ile olan bağı olduğu belirtilmektedir. Ayrıca Karşıyaka'nın uluslararası alanda tanınırlığının çok yetersiz olduğu, asgari seviyede var olan bu tanınırlığın ise Karşıyaka Spor Kulübü Basketbol branşı sayesinde elde edildiği söylenmektedir. Yaşar Holding Gıda Grubu Gıda İcra Başkan Yardımcısı ve KSK Yönetim Kurulu Üyesi Sn. Levent Dağhan Karşıyaka'nın tanınırlığı ile ilgili 
“Karşıyaka'nın tanınırlığı ancak bir takım uluslararası etkinliklere ev sahipliği yapması ile mümkün olacaktır. Monako Başbakan'ı Izmir'e neden gelir ki? Sadece Karşıyaka maçı için gelmiştir. Bu yüzden kulübün, Karşıyaka'nın uluslararası tanınırlığına inanılmaz katkısı vardır." ifadelerini kullanmaktadır.

Karşıyaka'nın çağrışımlarında Hergele Meydanı, vapur iskelesi, çarşısı, faytonları, balıkçı barınakları ve basketbolu gibi eski ve sembol ögelerin ağırlıklı olarak üzerinde durulduğu anlaşılmaktadır. Bununla birlikte Karşıyaka'daki özgür ortam, özgürlükçü insanlar, medeniyet ile olan bağ ve saygılı yapı Karşıyaka'yı çağrıştıran soyut kavramlar olarak dikkat çekmektedir.

Marka sadakati konusunda ise Karşıyaka'nın alışıımışın ötesinde bir seviyede yer aldığı ifade edilmektedir. Katılımcılar bu bağılığı "alışımışın dışında", "klasik hemşehriliğin ötesinde" ve "çocukluktan alınan bir aşı" şekilde tanımlamaktadır. Karşıyakalılar, bağlıı̆̆ ifade ederken 35,5 kavramında da görüldüğü üzere kentin tamamına değil ilçeye vurgu yapmakta, "İzmirli olmak" yerine "Karşıyakalı olmak" ifadesini kullanmaktadır. Söz konusu yaklaşım, İzmir başat kültüründen bütünüyle ayrılığı ifade etmek yerine, kozmopolit kent yapısından bir takım özgün özellikler itibarıyla farklılaşmış olmayı tanımlamak için kullanıldığı ifade edilmektedir. Ayrıca bu bağlılığın ilçeye göç eden insanlara da üst seviyeden sirayet eden bir etki alanına sahip olduğu belirtilmektedir. Karşıyaka Belediyesi Str. Gel. Müdürü Sn. Turan Ateş Karşıyaka'daki bağıılığı ve etki alanını "Karşıyaka'da yaşayanlara nereli olduğunu sorduğunuzda "Karşıyakalıyım" cevabını alırsınız. Buraya geldiğinizde o aidiyet duygusunu ediniyorsunuz, gerçekten buralı oluyorsunuz, burada yaşamaktan onur ve gurur duyuyorsunuz." ifadeleri ile belirtmektedir.

Karşıyaka'nın markalaşma stratejileri açısından değerlendirilmesine yönelik sorulan soruların yanıtları dikkate alındığında katılımcılara göre Karşıyaka ilçesinin marka olarak konumlandırılması noktasında yeteri kadar anlaşılır bir çalışmaya konu olmadığı ifade edilmekte, eğer konumlandırma çalışması yapılıyorsa da kamusal bilgilendirmenin ve ilçeye nüfuz etme düzeyinin yeterli olmadığı konusunda eleştirilmektedir. Bu sebeple katılımcılar tarafından, Karşıyaka'nın herkesçe anlaşılır ve kabul edilir bir konumlandırma çalışmasına ihtiyaç duyduğu ifade edilmektedir.

Markalaşma konusunda Karşıyaka'da uygulanan herhangi bir stratejik marka mimarisi modeline rastlanmadığı belirtilmektedir. Ege Ekonomiyi Geliştirme Vakfı Yönetim Kurulu Eski Başkanı, Karşıyaka Sanayici ve İş Adamları Derneği Kurucu Başkanı ve Temizocak Kuyumculuk ve Hassas Döküm San. ve Tic. A.Ş. Yönetim Kurulu Başkanı Sn. Yılmaz Temizocak bu konuda "Bağımlı markalamada olduğu gibi tek bir isim ile markalamanın uygun olacağını düşünüyorum. Ne olursa olsun tek bir isim olsun. Karşıyaka markası ile Karşıyaka Spor, Karşıyaka Sanat, Karşıyaka Yaşam vs. şeklinde uygulanması daha uygun olacaktır." şeklinde görüş belirtmektedir. Katılımcıların ifadeleri ile elde edilen bulgulara göre Karşıyaka'nın bağımlı marka mimarisi modeliyle kent markalaşma stratejisi uygulamasının, hem ilçenin mevcut yapısı hem ekonomik şartları hem de bütünlük gösterebilmesi açısından uygun olacağı ifade edilmektedir.

Karşıyaka'nın marka kent yaratma süreci açısından değerlendirilmesine yönelik sorulan sorularda Karşıyaka ilçesinin mevcut durumdaki güçlü ve zayıf yönleri, kent misyon ve vizyonu ile stratejik hedefleri tartışılmıştır. Bu bağlamda Karşıyaka'nın güçlü yönleri özgürlükçü, eğitimli, seçkin ve elit kabul edilen bir nüfusa sahip olması, üretim ve hareket kabiliyetinin yüksek olması, ilçede aidiyet duygusunun yüksek olması, güçlü, karakterli ve muhalif bir duruşa sahip olması, 35,5 gibi özgün ve geleneksel bir kültürünün olması, iyi bilinen bir ilçe olması, huzur ortamının egemen olması, kültür-sanat ve spor ile kuvvetli bir bağının olması, üretim ve hareket kabiliyetinin yüksek olması, ulaşım ağlarının gelişmiş olması ve coğrafi özellikleri itibarıyla yeşil ve mavinin kent yaşamındaki uyumu olarak ifade edilmektedir.

Bununla birlikte katılımcılara göre Karşıyaka ilçesinin zayıf yönleri şovenizme kayan ve aşırıya kaçan fanatik kültür yapısı, fiziki olarak büyüyemiyor olması ve buna rağmen emekli göçüne maruz kalması, ekonomik hareketliliğin az olması, çarpık kentleşme ve takip eden süreçte hatalı kentsel dönüşüme konu olması, uluslararası tanınırlığının az olması ve yabancı turist çekememesi, desteklerin gerçekliğe etkisinin asgaride kalması, nüfus yapısına ve potansiyeline uygun bir algı yaratamayıp kuvvetini gerçekliğe aktaramaması, spora yatırım yapılmaması ve tesis eksikliği, bireysel yaşam anlayışının hâkim kültür olması ve üniversite eksikliği olarak belirtilmektedir. 
Karşıyaka'nın hem ilçe bünyesinde hem de muadillerine göre bir takım fırsatları ve tehditleri de öngörülmektedir. Çağdaş ve üretken bir döneme girmesi, yerel yönetimlerinin kuvvetinin yüksek olması, karmaşık kent kültüründen uzak durabilmesi, sesinin ve akislerinin tüm yurda yayılabilme etkisi, genç nüfusun da Karşıyaka'yı tercih etmeye başlaması, yeni projelere uygun Yamanlar Dağı'nın turizm potansiyeli, nüfusunun kendi kendine yetebilecek donanımda olması, Kuzey İzmir'e projelendirilecek bir havaalanının turizme ve ticarete yapacağı katkı, İzmir Körfez ve İzmirdeniz - Kıyı Tasarım Projeleri'nin etkileri, coğrafi güzelliklerinin konsept olarak satılabilir olması, deniz turizmine ve deniz sporlarına uygun olması, kültür-sanat ve spor kenti olma potansiyeli Karşıyaka ilçesinin fırsatları olarak ifade edilmektedir.

Karşıyaka ilçesinin karşılaşabileceği tehditler yerel yönetimlerin yetersiz çalışması, çok göç alması, nüfus artışına bağlı kültür kirliliği ve toplumsal kaos ortamı, süregelen iktidar - yerel yönetim farklılı̆ı, dışa kapalı yapısı, yetersiz iş olanakları, fanatizme kayan yapı, Körfez Projesi'nin tünel harici bir yapıda gerçekleştirilme ihtimali, birlik ve bütünlük içerisinde hareket edememesi, sağılı ve spor turizminin şiddetle inmal edilmesi, stadyum eksikliği, stadyumun otoyol, izBAN, tramvay gibi ulaşım ağlarının dışına inşa edilmesi olasılı̆ı̆ olarak belirtilmektedir.

Kent markalaşması açısından önemli olan, kent için kapsayıcılığı ve bütünlüğünü ifade eden kent misyon ve vizyonu ise sözcüklerin anlamları itibarıyla ağırlıklı olarak Karşıyaka ile özdeşleşen kavramlar olarak ifade edilmektedir. Bununla birlikte taslak/şablon olarak da nitelendirilen söz konusu ifadelerin Karşıyakalılarla, Karşıyaka gerçekleri ve meziyetleri ile daha güçlü bağlar kurması gerektiği de ifade edilmektedir. Yerel yönetimlerin tek elinde olmayan, olası yönetsel değişimlerle birlikte değişime uğramayacak, kapsayıcı, ortak akıl ile belirlenmiş zenginlikte olması gerektiği söylenmektedir.

Katılımcılar, Karşıyaka ilçesinin stratejik hedeflerinde kültür-sanat, spor ve kentleşme alanları ile daha bütünleşik bir çalışma sahasına ihtiyaç duyduğunu belirtmektedir. Stratejik planlarda akademi, sanayi, ticaret gibi alanların ve kentli görüşlerinin yoğun şekilde bulunması, ilçenin mevcut yeteneklerinin stratejik plan ile daha görünür kılınması, Karşıyaka'ya özgü özelliklerin ağırlığının artııılması, daha doyurucu bir bütçe ve proje temeli ile hareket edilmesi gerektiği ifade edilmektedir.

\section{Sonuç ve Öneriler}

Günümüzde markalaşma, sağladığı faydalar itibarıyla yalnızca ürün ve hizmetlerin değil, pastadan daha büyük pay almak isteyen her kurum ve kuruluşun konusu olmaktadır. Bu durum kentleri de markalaşma sürecine yöneltmekte ve muadillerinden farklılaşan kentlere finansal, kültürel, psikolojik vb. birçok avantaj sağlamaktadır. Uzun vadeli, planlı ve stratejik süreçlere intiyaç duyan markalaşma kavramı kentler için bir kimlik, kişilik ve imaj yaratmayı, nasıl algılandığını önemsemeyi, hedef pazara uygun bir konumlandırma yaratmayı kıymetli ve zorunlu hale getirmiştir.

Bu çalışmada, Karşıyaka ilçesinin markalaşmış bir kent olma yolunun neredeyse başında olduğu ancak kültür, sanat ve spor alanlarında yüksek bir potansiyele sahip olduğu görülmektedir. illçenin markalaşmasında, Karşıyaka'nın tamamını kapsayacak ana bir marka ile bağımlı marka mimarisi modelini kullanarak öne çıkan bu alanlarda rakiplerine karşı fark yaratabileceği elde edilmiştir.

Karşıyaka ilçesinin marka kimliği, kişiliği, imajı, çağrışımları, sadakat seviyesi gibi unsurlar dikkate alındığında 35,5 kavramının ilçenin tamamını kapsayıcı bir kavram olduğu, ilçeyi temsil edecek ana marka olarak kullanılabileceği düşünülmektedir. İlçe için sembol renkler olan yeşil ve kırmızının 35,5 logosuna uygulanabileceği, "Biz Karşıyakalıyız" gibi benimsenen sloganlar ile Karşıyaka ilçesinin tamamını kapsayıcı bir markaya dönüştürülebileceği ortaya çıkmaktadır.

Karşıyaka ilçesinin kültürel olarak geçmişine bağlılığı ve sadakat seviyesi göz önünde bulundurulduğunda Portofino, Churcill, Hergele Meydanı, Melek Sineması, Tilla ve Palet Restoran gibi nostaljik ögelerin bugünün Karşıyaka'sına gerek yerel yönetim işletmelerince, gerekse farklı düzenlemelerle entegre edilebileceği düşünülmektedir. Yine ilçedeki kültür-sanat alanlarının ve nirengi noktalarının Karşıyaka için büyük önem taşıyan Attila illhan, Salah Birsel, Şükran Kurdakul, Yaşar Aksoy gibi değerler ile isimlendirilmesi değerlendirilebilir. Ayrıca Karşıyaka ve Bostanlı Vapur İskelelerinin tamamı ile kamusal alana 
dâhil edilerek kütüphane, gençlik merkezi, çocuk gelişim merkezi vb. olarak kullanılması düşünülebilir. Söz konusu uygulamaların Karşıyaka'da bağılığı ve sadakati artırıcı ve sosyal, özgürlükçü ve hoşgörülü ilçe kültürü ile uyumlu bir uygulama olacağı düşünülmektedir.

Karşıyaka ilçesinin markalaşma çalışmalarında özellikle kültür-sanat ve spor alanlarına öncelik vermesi gerektiği düşünülmektedir. Karşıyaka'nın tanınırlığında temel unsurlar olarak da değerlendirilen söz konusu alanlar, Karşıyaka'nın markalaşmasında öncül alanlar olarak değerlendirilmektedir. Kültür-sanat alanlarının hem nitelik olarak zenginleştirilmesi, hem de niceliklerinin artırılması markalaşma noktasında fiziksel kanıt olarak hem kentliye hem de kentin görüntüsüne önemli katkılar sağlayacaktır. Ayrıca ilçede inşaatı devam eden opera binasının Zübeyde Hanım Opera Binası olarak isimlendirilmesinin ilçenin kimliği, imajı, kültürel değerleri ve çağrışımları ile uyumlu olacağı değerlendirilmektedir.

Karşıyaka'nın ulusal ve uluslararası alanda tanınırlığındaki önemli faktörlerden birisi de Karşıyaka Spor Kulübü olarak değerlendirilmektedir. İlçenin kültür-sanat ve spor alanında markalaşmasının uygun olacağı dikkate alındığında kulübün yerel yönetimlerce daha emin ve sürekli desteklenmeye ihtiyaç duyduğu düşünülmektedir. Ayrıca ilçenin hem Karşıyaka Spor Kulübü'ne hem de Karşıyaka'nın markalaşmasına katkı sağlayacak bir stadyuma, uluslararası standartlarda bir spor salonuna ve amatör sporlarda daha üst düzey tesislere ihtiyaç duyduğu değerlendirilmektedir. Bununla birlikte kültür-sanat ve spor alanlarının hem kent vizyonunda hem de stratejik planlarda daha görünür kılınmasının ve uygulanmasının önemli olacağı düşünülmektedir.

Tüm bu süreçlerin, Karşıyaka'nın markalaşması konusunda bir düzen içerisinde yürütülecek stratejik çerçeveye oturtulması gerekmektedir. Bunun için markalaşma stratejilerinde bağımlı marka mimarisi modeli uygulanarak yaratılacak ana marka ile (Örneğin 35,5 markası) gerçekleştirilmesi uygun olacaktır. Karşıyaka'da gerçekleştirilen tüm faaliyetler 35,5 ana marka çatısı altında "35,5 Spor", "35,5 Sanat", "35,5 Yaşam" vb. şekilde uygulanması düşünülebilir. Böylelikle kültür-sanat ve spor alanlarına yönelerek kentlerin yaşadığı çoklu imaj zorluklarının, bağımlı marka mimarisi modeli ile yaratılacak ana marka vesilesiyle de anlaşılır şekilde markalaşamama zorluğunun önüne geçilebilir.

Karşıyaka ilçesinde bulunan Yamanlar Dağı doğa turizmi alanında yerli ve yabancı turistlerin ilgisini çekecek hale getirilebilir. Bölgede gerçekleştirilecek doğa yürüyüşü, doğa fotoğrafçılığı, kampçılık, paintball vb. etkinlikler ile bölge daha aktif bir şekilde değerlendirilebilir. Ayrıca bölgenin doğal yapısını bozmadan, bahse konu bölgeye ve çevresine konaklama alanları yaparak, ilçenin en ciddi eksiklerinden olan konaklama alanı açığının da kapanması sağlanabilir. İlave olarak ilçenin markalaşması sağlayacak bir "Kültür, Sanat ve Spor Festivali" düzenlenmesi düşünülebilir. Bu festival kapsamında sahil şeridi boyunca uzanan Atatürk, Annesi ve Kadın Hakları Anıtı, Kadın Heykelleri, Insan Hakları Anıtı, Uçan Yunuslar Heykeli, Demokrasi Meydanı ve Zübeyde Hanım Opera Binası dikkate alındığında, söz konusu anıtların olduğu bölgede anıtların isimleri ile örtüşen "Kadın Hakları Atölyesi", "Insan Hakları Atölyesi", "Barış Atölyesi", "Demokrasi Atölyesi" oluşturarak müzik dinletilerinin de gerçekleştirildiği uluslararası katılımcılı bir yapı oluşturulabilir. Sahilde bulunan basketbol, bisiklet, yelken, koşu vb. alanlar turnuvalara konu edilerek festivale dâhil edilebilir. Kapanış programı ise Zübeyde Hanım Opera Binası'nda STK'ların, yerel yönetimlerin, yerel halkın ve uluslararası katılımcıların bulunacağı bir törenle "Kadın Hakları", "İnsan Hakları", "Demokrasi”, "Barış" ve "Spora Destek" gibi ödüllerin dağıtıldığı bir organizasyona dönüştürülebilir.

Tüm bu süreçlerde Karşıyakalıların talep ve beklentilerini bütünlük içerisinde beyan edecek, ilçenin temiz, huzurlu ve daima güvenilir olmasına odaklanacak, Karşıyaka'nın markalaşmasına destek sağlayacak STK'ların oluşturulması da sürece önemli katkılar sağlayacaktır. Söz konusu STK'ların ilçe paydaşlarına temas edeceği, farkındalığı artıracağı, diğer STK'lar ile entegrasyonu sağlayacağı düşünülmektedir.

Sonuç olarak çalışmadan elde edilen bulgulara göre Karşıyaka ilçesinin markalaşmasında ortaya konulacak en büyük çabanın Karşıyaka Belediyesi bünyesinde bir çatı girişim olarak tamamen Karşıyaka'nın markalaşması için çalışacak bağımsız bir komisyon kurulması olduğu önerilmektedir. Söz konusu komisyonun diğer komisyon ve birimlerle etkileşim içinde, ilçenin markalaşması adına çalışma hususunda tüm iç ve dış birimlerin, aktörlerin ve profesyonellerin desteğini alan ve onlara destek veren markalaşma çalışmalarının toplandığı bir ana merkez gibi faaliyet göstermelidir. Bu komisyon uzun vadeli olarak Karşıyaka ilçesinin marka 
kimliğini yaratmak, kişiliğini yansıtmak ve geliştirmek, arzu edilen imajı ve konumu oluşturmak, marka kent olabilmek adına gerekli vizyon, amaç, hedef vb. girişimleri gerçekleştirmek, başarılı örneklerle kıyaslama yapmak/referans noktası belirlemek (benchmarking), gerekli görüldüğü takdirde markalaşmış kentlerden kent markalaşması hususunda destek almak, tüm paydaşlar nezdinde markalaşma çabalarının bütünleşmesini sağlamak görev ve sorumluluklarını üstlenebilir. Karşıyaka'nın markalaşması sürecinin stratejik bir bakış açısı ile programlanıp kurumsal bir çatı ve vizyon altında yönetilmesi durumunda ilçenin markalaşma açısından oldukça gelecek vaat edici olduğu söylenebilir.

\section{Teşekkür}

Çalışmanın araştırma bölümünde değerli zamanlarını, bilgi ve birikimlerini benden esirgemeyen büyüklerim Sn. Yaşar AKSOY, Sn. Cihan TÜRSEN, Sn. Turan ATEŞ, Sn. Turgay BÜYÜKKARCI, Sn. Levent DAĞHAN ve Sn. YIImaz TEMIZOCAK'a saygılarımı ve teşekkürlerimi sunmayı bir borç bilirim.

\section{Son Notlar}

* Bu çalışma Berkay ÖZKAYA’nın “Kent Markalaşması Faaliyetleri Üzerine Bir Araştırma: Karşıyaka/izmir Örneği” isimli yüksek lisans tezinden üretilmiştir.

\section{Kaynaklar}

Aaker, D. A., (1996). Building strong brands. New York: Free Press.

Aaker, D. A., (2009). Marka değeri yönetimi (Çev. E. Orfanlı). ìstanbul: MediaCat Yayınları.

Aaker, D. A.,, \& Joachimsthaler, E., (2000). The brand relationship spectrum: The key to the brand architecture challenge. California Management Review, 42(4), 8-23.

Açıkgöz, Ö., (2007). Şehir, şehir toplumu ve şehir sosyolojisi. Sosyoloji Konferansları Dergisi, 35, 57-83.

Akturan, U., \& Oğuztimur S. (2016). Kent markalaşması kavramının içeriği ve gelişimi: Farklı disiplinler farklı yaklaşımlar. Planlama Dergisi, 26(2), 117-129.

Altunbaş, H. (2007). Pazarlama iletişimi ve şehir pazarlaması "şehirlerin markalaşması". Selçuk Üniversitesi iletişim Fakültesi Akademik Dergisi, 4(4), 156-162.

Anholt, S. (2006). The Anholt-GMI city brands Index how the world sees the world's cities. Place Branding, 2(1), 18-31.

Aray, G., (2009). Marka konumlandırma ve şehir markaları: Burdur şehrinin markalaşmasına yönelik bir uygulama. Dokuz Eylül Üniversitesi Sosyal Bilimler Enstitüsü, Yüksek Lisans Tezi, İzmir.

Arslan, C. (2015). Şehir markalaşmasının pazarlama açısından öne çıkan faktörlerinin değerlendirilmesi ile ilgili bir araştırma. Dokuz Eylül Üniversitesi Sosyal Bilimler Enstitüsü, Yüksek Lisans Tezi, İzmir.

Avcılar, M. Y., \& Kara, E., (2015). Şehir markası kavramı ve marka şehir yaratma stratejilerine yönelik literatür incelemesi. Sosyal ve Beşeri Bilimler Araştırmaları Dergisi, 34, 76-94.

Avraham, E. (2004). Media strategies for improving an unfavorable city ımage. Cities, 21(6), 471-479.

Bakır, M., Bal, H. T., \& Akan, Ş., (2017). Türk sivil havacilık sektörünün değerlendirilmesinde bütünleşik SWOT-AHS yaklaşımı. Journal of Aviation, 1(2), 154-169.

Baş̧ı, A. (2006). Şehir markası yaratma süreci ve İstanbul şehir markası için bir model önerisi. Marmara Üniversitesi Sosyal Bilimler Enstitüsü, Yüksek Lisans Tezi, İstanbul.

Başer, H. H. (2015). Kent imajı oluşumuna etki eden unsurların kentin markalaşması sürecindeki rolü: Konya örneği. Selçuk Üniversitesi Sosyal Bilimler Enstitüsü, Yüksek Lisans Tezi, Konya.

Başpınar, O. (2015). Şehir markalaşması ve Ankara örneği. Türk Patent Enstitüsü, Markalar Daire Başkanlığı, Uzmanlık Tezi, Ankara.

Berg, B. L. (2001). Qualitative research methods for social scientists. Boston: Allyn \& Bacon. 
Büyüksoy, B. (2008). City branding: İstanbul case study. Yeditepe Üniversitesi Sosyal Bilimler Enstitüsü, Yüksek Lisans Tezi, İstanbul.

Coşkun, K., Yıldız, S. M., \& Çatı, K., (2004). Kent markalaşması ve marka imajı ölçümü açısından Düzce ili örneği. Düzce Üniversitesi Sosyal Bilimler Enstitüsü Dergisi, 4(2), 65-83.

De Carlo, M., Canali, S., Pritchard, A., \& Morgan, N., (2009). Moving Milan towards Expo 2015: Designing culture into a city brand. Journal of Place Management and Development, 2(1), 8-22.

Egeli, G. Z. (2017). City brandings as a tool for developing the cities: A case study for İzmir. Dokuz Eylül Üniversitesi Sosyal Bilimler Enstitüsü, Yüksek Lisans Tezi, İzmir.

Gökerik, M. (2013). Şehir markalaşmasının girişimcilik eğilimi üzerine etkisi: Uşak ili örneği. Selçuk Üniversitesi Sosyal Bilimler Enstitüsü, Yüksek Lisans Tezi, Konya.

Görkemli, N. H. (2012). Kent imajı ve markalaşan kentler. Akdeniz Üniversitesi Iletişim Fakültesi Dergisi, 17, $141-155$.

Hacıoğlu, H. A. (2013). Şehir pazarlaması ve şehir markalaşması çerçevesinde şehir imaj algısının ölçümü: Eskişehir'de bir uygulama. Dumlupınar Üniversitesi Sosyal Bilimler Enstitüsü, Yüksek Lisans Tezi, Kütahya.

Hancock, D. R., \& Algozzine, B. (2006). Doing case study research - a practical guide for beginning researchers. New York: Teachers Collage Press.

Hanna, S., \& Rowley, J. (2007). An analysis of terminology use in place branding. Place Branding and Public Diplomacy, 4(1), 61-75.

İçyer, A. (2010). Marka kent oluşturma açısından stratejik kent yönetimi. Karamanoğlu Mehmetbey Üniversitesi Sosyal Bilimler Enstitüsü, Yüksek Lisans Tezi, Karaman.

Kavaratzis, M. (2004). From city marketing to city branding: Towards a theoretical framework for developing city brands. Place Branding, 1(1), 58-73.

Kavaratzis, M. (2009). Cities and their brands: Lessons from corporate branding. Place Branding and Public Diplomacy, 5, 26-37.

Kavaratzis, M., \& Ashworth, G. J. (2005). City branding: An effective assertion of identity of a transitory marketing trick? Tijdschrift Voor Economische en Sociale Geografie, 96(5), 506-514.

Kaypak, Ş. (2010). Antakya'nın kent kimliği açısından irdelenmesi. Mustafa Kemal Üniversitesi Sosyal Bilimler Enstitüsü Dergisi, 7(14), 373-392.

Keegan, S. F. (2009). Qualitative research good decision making through understanding people, cultures and markets. Londra: Kogan Page Publishing.

Kırgız, A. C. (2011). Şehir markalaşmasının pazarlama estetiği ile desteklenmesi ve İstanbul örneği. Marmara Üniversitesi Sosyal Bilimler Enstitüsü, Doktora Tezi, İstanbul.

Lincoln, Y. S., \& Guba, E. G. (1985). Naturalistic inquiry. USA: Sage Publications.

Mariotti, J. (2000). Smart things to know about brands and branding. Capstone: Capstone Publishing Limited.

Merriam, S. B. (2013). Nitel araştırma, desen ve uygulama için bir rehber (Çev. S. Turan). Ankara: Nobel Yayıncılık.

Mills, A. J., Durepos, G., \& Wiebe, E. (2010). Encyclopedia of case study research (Vol. 1). Londra: Sage Publications.

Nakip, M., \& Yaraş, E. (2017). SPSS uygulamalı pazarlamada araştırma teknikleri (4. Baskı). Ankara: Seçkin Yayıncılık.

Özden, A. T. (2013). Şehir markalaşması ve Samsun örneği. Ondokuzmayıs Üniversitesi Sosyal Bilimler Enstitüsü, Yüksek Lisans Tezi, Samsun.

Pala, U. (2013). Destinasyon markası olma süresince Tarsus. Mersin Üniversitesi Sosyal Bilimler Enstitüsü, Yüksek Lisans Tezi, Mersin.

Parkerson, B., \& Saunders, J. (2005). City branding: Can goods and services branding models be used to brand cities? Place Branding, 1(3), 242-264.

Peker, A. E. (2006). Kentlerin markalaşma sürecinde çağdaş sanat müzelerinin rolü: Kent markalaşması ve küresel landmark. İstanbul Teknik Üniversitesi Fen Bilimleri Enstitüsü, Yüksek Lisans Tezi, İstanbul.

Polat, S., Polat, S. A., \& Halis, M., (2013). Kent kimliği kapsamında festivallerin değerlendirilmesi: Uluslararası Altın Safran Film Festivali Örneği. Turizm \& Araştırma Dergisi, 2(1), 48-63.

Prayag, G. (2009). Brand image assessment: International visitors' perceptions of Cape Town. Marketing Intelligence \& Planning, 28(4), 462-485.

Punch, K. F. (2014). Sosyal araştırmalara giriş, nitel ve nicel yaklaşımlar (Çev. D. Bayrak, H. B. Arslan, Z. Akyüz). Ankara: Siyasal Kitabevi. 
Rainisto, K. S. (2003). Success factors of place marketing: A study of place marketing practices in Northern Europe and The United States. Helsinki University of Technology Institute of Strategy and International Business Doctoral Dissertaations, Helsinki.

Rajagopal \& Sanchez, R. (2004). Conceptual analysis of brand architecture and relationships within product categories. Brand Management, 11(3), 233-247.

Ritchie, J., \& Lewis, J. (2003). Qualitative research practice: A guide for social science students and researchers. Londra: Sage Publications.

Seisdedos, G., \& Vaggine, P. (2005). The city branding processes: The case of Madrid. 41st ISoCaRPCongress, 1-10.

Seyhan, E. (2007). Markalaşma sürecinde bütünleşik pazarlama iletişiminin yeri ve önemi. Gazi Üniversitesi Sosyal Bilimler Enstitüsü, Yüksek Lisans Tezi, Ankara.

Stake, R. E. (2005). Qualitative case studies içinde Denzin, N. K. ve Lincoln, Y. S. (Eds.), The Sage Handbook of Qualitative Research (3rd ed.) Thousand Oaks, CA: Sage Publications, 445-446.

Stake, R. E. (2010). Qualitative Research: Studying How Things Work. London: The Guildford Press.

T.C. Başbakanlık, (2006). Devlet Planlama Teşkilatı, kamu idareleri için stratejik planlama kılavuzu, (2. Sürüm). http://www.sp.gov.tr/tr/kutuphane/s/55/ (Erişim Tarihi: 18 Nisan 2018).

Torlak, M. (2015). Marka şehir oluşturma ve bursa şehrinin markalaşması için yol haritası. Tüketici ve Tüketim Araştırmaları Dergisi, 7(2), 47-93.

Toksarı, M., İsen, İ., \& Dağcı, A. (2014). Bir şehrin markalaşması ve pazarlanması süreci: Konya ilinde bir uygulama. Niğde Üniversitesi iiBF Dergisi, 7(1), 328-343.

Varlı, B. (2011). Kent markalaşması sürecinde iletişim temelli faaliyetlerin analizi: İstanbul 2010 Avrupa Kültür Başkenti örneği. Kocaeli Üniversitesi Sosyal Bilimler Enstitüsü, Yüksek Lisans Tezi, Kocaeli.

Yıldırım, A. (1999). Nitel araştırma yöntemlerinin temel özellikleri ve eğitim araştırmalarındaki yeri ve önemi. Eğitim ve Bilim, 23(112), 7-17.

Yin, R. K. (2002). Case study research (Design and methods). California: Sage Publication.

Zeren, H. E. (2011). Stratejik kent yönetimi ve kent markası oluşturma süreci. Kahramanmaraş Sütçü Imam Üniversitesi iktisadi ve Idari Bilimler Fakültesi Dergisi, 1(2), 175-200.

http://bleacherreport.com/articles/2368899-10-best-sports-cities-in-the-world (Erişim Tarihi: 06 Şubat 2018).

http://www.genctur.com.tr/oktoberfest/ (Erişim Tarihi: 06 Şubat 2018).

https://burningman.org/network/about-us/ (Erişim Tarihi: 06 Şubat 2018).

https://www.cntraveler.com/galleries/2014-09-19/the-world-s-best-cities-for-arts-and-culture-lovers (Erişim Tarihi: 06 Şubat 2018).

https://www.iaa.de/en/iaa/history/ (Erişim Tarihi: 06 Şubat 2018).

https://www.topuniversities.com/subject-rankings/2017 (Erişim Tarihi: 06 Şubat 2018).

http://www.wimbledon.com/en_GB/atoz/history.html (Erişim Tarihi: 06 Şubat 2018). 